\title{
Delivery of Probiotic Microorganisms into Gastrointestinal Tract by Food Products
}

\author{
Amir Mohammad Mortazavian'1, \\ Reza Mohammadi ${ }^{1}$ and Sara Sohrabvandi ${ }^{2}$ \\ ${ }^{1}$ Department of Food Science and Technology, \\ National Nutrition and Food Technology Research Institute, \\ Faculty of Nutrition Sciences and Food Technology, \\ Shahid Beheshti University of Medical Sciences, Tehran \\ ${ }^{2}$ Students Research Committee, Department of Food Science and Technology, \\ National Nutrition and Food Technology Research Institute, \\ Faculty of Nutrition Sciences and Food Technology, \\ Shahid Beheshti University of Medical Sciences, Tehran
}

Iran

\section{Introduction}

The health of gastrointestinal tract affects by numerous factors and probiotics are of the most important. There are two main ways to increase the population of viable probiotic bacteria within the human body: 1) adequate daily nutrition as well as avoiding factors and stresses lead to decrease in probiotics in vivo viable population, and 2) ingestion of high viable population of probiotics. The common, widespread and popular method to ingest high viable population of probiotics is via food products consumption. Probiotic food products are regarded as an important group of 'functional foods'.

Today, there is a strong increase in the consumption of probiotic bacteria using food products, mainly probiotic dairy products. Also, recently, many probiotic non-dairy products have been developed. Therefore, the manufacture of dairy- and nondairy products containing probiotic bacteria is an important issue with industrial and commercial consequences and many products of this kind are available in the world market.

Viability of probiotic bacteria (the number of viable and active cells per $\mathrm{g}$ or $\mathrm{mL}$ of probiotic food products at the time of consumption) is the most critical value for these products because it determines their healthful efficiency. Therefore, it is important to ensure a high survival rate of the probiotic bacteria during production as well as during the storage time. Many complicated and inter-related factors influence the viability of probiotic microorganisms in each food product during production and storage. Apart from the viability of probiotics in products until the time of consumption, their survival in food matrices after exposure to gastrointestinal tract (GIT) conditions is crucial. They must arrive viable and active to different parts of intestine, adhere and colonize. Some factors affect viability of probiotics during delivery into the intestine while they are enclosed in food 
matrices. In this chapter, the concept of ingestion and delivery of probiotic microorganisms via food products are discussed.

\section{Probiotic food products}

Probiotic microorganisms are available in three different types for direct or indirect human consumption: 1) culture concentrate to be added to a food (dried or deep-freeze form) for industrial or home uses, 2) food products (fermented or non-fermented), and 3) dietary supplements (drug products in powder, capsule or tablet forms) (Tannis, 2008). Consumption of probiotic cells via food products are the most popular and widespread way.

Worldwide, the demand for consumption of functional foods is growing rapidly due to the increased awareness of the consumers from the impact of food on health. For example, in the year 2000, the world-wide market of functional foods generated US\$ 33 billion, in 2005, this total was US\$ 73.5 billion, and was US\$ 167 billion in 2010 (Granato et al., 2010). Functional foods are those that contain chemical/microbial components that may affect beneficially one or more target functions in the body, beyond adequate nutritional effects, in a way that is relevant to either the state of well-being and health or the reduction of the risk of a disease (Diplock et al., 1999). Probiotic food products are classified in the category of functional foods and represent a significant part of this market that probiotic foods comprise between 60 and $70 \%$ of the total functional food market (Holzapfel, 2006).

During the past three decades, significant attention has been paid to dairy products containing probiotic bacteria such as fermented milks, ice cream, various types of cheese, baby-food, milk powder, frozen dairy desserts, whey-based beverages, sour cream, butter milk, normal and flavored liquid milk, and concentrated milk. Also, recently, many nondairy products such as vegetarian-based products, cereal-based products, fruit juice, soyabased products, oat-based desserts, confectionary products, breakfast cereals and baby foods) and baby foods have been developed. Causes for this ongoing trend are demands provide by vegetarianism, high prevalence of lactose intolerance in many populations around the world, and providing variety and development in probiotic food products (Granato et al., 2010; Mortazavian et al., 2011). Dairy products have the largest probiotic food market share. Today, a total of $78 \%$ of current probiotic sales in the world are delivered through yogurt (Cargill, 2009). Therefore, still, the manufacture of dairy products containing probiotic bacteria is an important issue with industrial and commercial consequences. Table 1 represents some types of probiotic products available in the world market (dairy and nondairy products). Figure 1 indicates qualitative aspects of probiotic food products.

\section{Probiotic microorganisms used in food products}

It is clear that the right selection and application of a probiotic strains in food materials exhibits fundamental impacts on qualitative aspects of final products, namely safety (related to the mentioned strains), health benefits (related to probiotics), sensory attributes and even, the price. Therefore, selecting the adequate probiotic strains is the first prerequisite for designing a specific probiotic food product. The incorporation of incorrectly identified probiotic bacteria in functional food products clearly has public health implications, by undermining the efficiency of probiotics and by affecting public confidence in functional 
foods (Huys et al., 2006). Thus, the use of adequate tools to provide proper strain identification for legal and good manufacturing practices and to track probiotics during food production as well as during their intestinal transit are strictly necessary (Lee and Salminen, 2009).

\begin{tabular}{|c|c|c|c|}
\hline Dairy products & Reference & Non dairy products & Reference \\
\hline Regular full-fat yogurts & Aryana and Mcgrew (2007) & Vegetable-based drinks & Lambo et al. (2005) \\
\hline $\begin{array}{l}\text { Iranian yogurt drink } \\
\text { (Doogh) }\end{array}$ & Mortazavian et al. 2008 & Fermented banana & Tsen et al. (2009) \\
\hline Acidophilus milk drink & Itsaranuwat et al. (2003) & Tomato-based drink & Yoon et al. (2004) \\
\hline Stirred fruit yogurts & Kailasapathy et al. (2008) & Many dried fruits & Betoret et al. (2003) \\
\hline $\begin{array}{l}\text { Dairy fermented } \\
\text { beverage }\end{array}$ & $\begin{array}{l}\text { Shobharani and Agrawal } \\
\text { (2009) }\end{array}$ & Green coconut water & Prado et al. (2008a) \\
\hline $\begin{array}{l}\text { Whey-protein-based } \\
\text { drinks }\end{array}$ & Dalev et al. (2006) & Peanut milk & Mustafa et al. (2009) \\
\hline $\begin{array}{l}\text { Synbiotic acidophilus } \\
\text { milk }\end{array}$ & Amiri et al. (2008) & $\begin{array}{l}\text { Cranberry, pineapple, } \\
\text { and orange juices }\end{array}$ & Sheehan et al. (2007) \\
\hline Cheddar cheese & Ong and Shah (2009) & Ginger juice & Chen et al. (2008) \\
\hline Feta cheese & $\begin{array}{l}\text { Kailasapathy and } \\
\text { Masondole } \\
\text { (2005) }\end{array}$ & $\begin{array}{l}\text { Grape and passion fruit } \\
\text { juices }\end{array}$ & Saarela et al. (2006) \\
\hline Cheese from caprine mil & Kalavrouzioti et al. (2005) & $\mathrm{Cabb}$ & Yoon et a \\
\hline $\begin{array}{l}\text { Semi-hard reduced-fat } \\
\text { cheese }\end{array}$ & Thage et al. & Carr & Nazzaro \\
\hline White-brined cheese & Yilm & Non & Wa \\
\hline Minas Fresco cheese & Souza and Saad (2009) & Onion & $\begin{array}{l}\text { Roberts and Kidd } \\
(2005)\end{array}$ \\
\hline Cottage cheese & Blanchette et al. (1996) & $\begin{array}{l}\text { Nonfermented fruit juice } \\
\text { beverages }\end{array}$ & Renuka et al. (2009) \\
\hline $\begin{array}{l}\text { Canestrato Pugliese hard } \\
\text { cheese }\end{array}$ & Corbo et al. & $\begin{array}{l}\text { nted soy-based } \\
\text { serts }\end{array}$ & 005) \\
\hline Argentine Fresco cheese & Vinderola et al. (2000b) & Fermented soymilk drink & kDonkor et al. (2007) \\
\hline Goat semi-solid cheese & Gomes and Malcata (1999) & Soy-based sti & Saris et al. (2003) \\
\hline $\begin{array}{l}\text { Manufacture of Turkish } \\
\text { Beyaz cheese }\end{array}$ & Kilic et al. (2009) & Rice-based yogurt & Helland et al. (2005) \\
\hline $\begin{array}{l}\text { Iranian White-brined } \\
\text { cheese }\end{array}$ & $\begin{array}{l}\text { Ghoddusi and Robinson } \\
\text { (1996) }\end{array}$ & Oat-based drink & Angelov et al. (2006) \\
\hline White-brined cheese & özer et al. (2008) & Oat-based products & $\begin{array}{l}\text { Martensson et al. } \\
(2002)\end{array}$ \\
\hline Minas & Sou & Oat-1 & Blandino et al. (2003) \\
\hline Synbiotic ice cream & Homayouni et al. (2008) & $\begin{array}{l}\text { Fermented maize } \\
\text { beverage }\end{array}$ & McMaste et al. (2005) \\
\hline Fermented goat's milk & Mart'in-Diana et al. (2003) & $\begin{array}{l}\text { Wheat fermented } \\
\text { probiotic beverages }\end{array}$ & Blandino et al. (2003) \\
\hline Probiotic ice cream & $\begin{array}{l}\text { Kailasapathy and Sultana } \\
\text { (2003) }\end{array}$ & Malt-based drink & Kedia et al. (2007) \\
\hline Low-fat ice cream & $\begin{array}{l}\text { Haynes and Playne (2002) } \\
\text { Akalin and Erisir (2008) }\end{array}$ & $\begin{array}{l}\text { Millet or sorghum flour } \\
\text { fermented probiotic } \\
\text { beverage }\end{array}$ & Muianja et al (2003) \\
\hline
\end{tabular}




\begin{tabular}{|c|c|c|c|}
\hline Dairy products & Reference & Non dairy products & Reference \\
\hline $\begin{array}{l}\text { Mango soy fortified } \\
\text { probiotic yogurt }\end{array}$ & Kaur et al (2009) & $\begin{array}{l}\text { Starch-saccharified } \\
\text { probiotic drink }\end{array}$ & $\begin{array}{l}\text { Oi and Klitabatake } \\
(2003)\end{array}$ \\
\hline Frozen yogurt & Davidson et al. (2000) & Meat products & Rouhi et al. (2010) \\
\hline Frozen synbiotic dessert & & $\begin{array}{l}\text { Tempeh (base on } \\
\text { soybean) }\end{array}$ & Feng et al. (2005) \\
\hline Acidophilus butter & Gomes and Malcata (1999) & Chocolate & Possemiers et al. (2010) \\
\hline $\begin{array}{l}\text { Traditional Greek } \\
\text { yogurt }\end{array}$ & $\begin{array}{l}\text { Maragkoudakisa et al. } \\
(2006)\end{array}$ & & \\
\hline Frozen dairy dessert & Shah and Ravula (2000) & & \\
\hline Corn milk yogurt & $\begin{array}{l}\text { Supavititpatana et al. } \\
(2008)\end{array}$ & & \\
\hline $\begin{array}{l}\text { High pressure- } \\
\text { homogenized } \\
\text { probiotic fermented } \\
\text { milk }\end{array}$ & Patrignani et al. (2009) & & \\
\hline Banana-based yogurt & Sousa et al. (2007) & & \\
\hline $\begin{array}{l}\text { Mango soy fortified } \\
\text { probiotic yogurt }\end{array}$ & Kaur et al. (2009) & & \\
\hline Yog-ice cream & El-Nagar et al. (2002) & & \\
\hline
\end{tabular}

Table 1. Some types of probiotic products available in the world market (dairy and non dairy products)

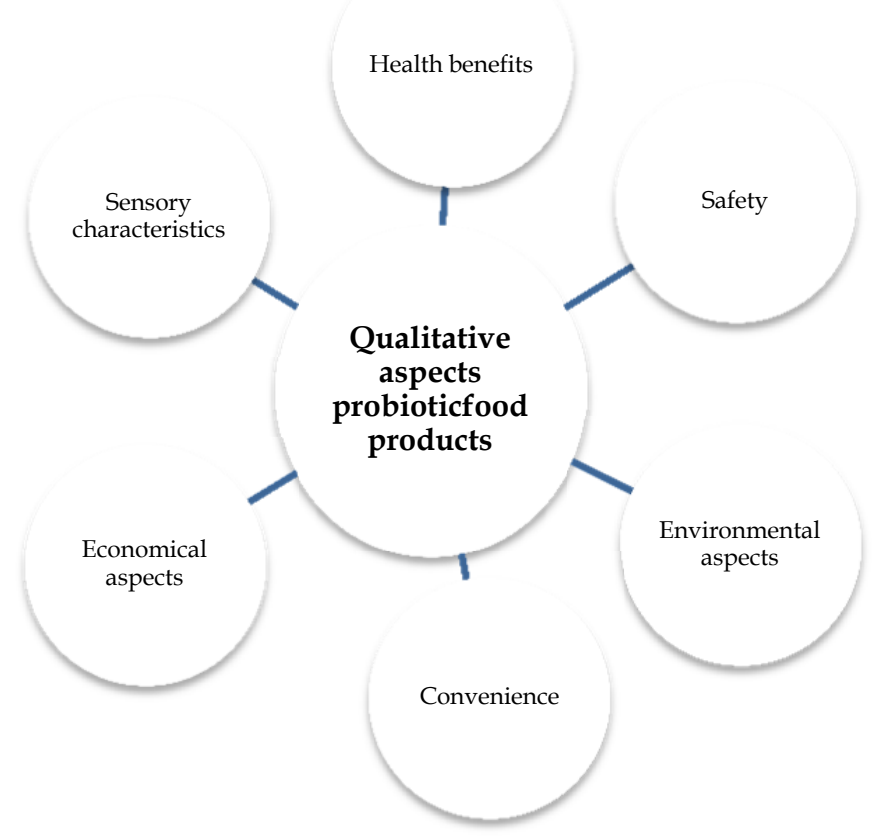

Fig. 1. Qualitative aspects of probiotic food products. 
Many of the bacteria used in probiotic preparations (bifidobacteria and lactic acid bacteria) have been isolated from human fecal samples to maximize the likelihood of compatibility with the human gut microflora and improve their chances of survival (Andersson et al., 2001). Microorganisms isolated from fermented nondairy foods have shown these abilities in in vitro studies (Rivera-Espinoza and Gallardo-Navarro, 2010). Probiotic organisms are predominantly bacteria selected from the genera Lactobacillus and Bifidobacterium, which are normal constituents of the human intestinal microbiota. However, species belonging to the genera Lactococcus, Enterococcus, Saccharomyces and Propionibacterium are also considered as probiotic due to their health-promoting effects (Blandino et al., 2003; Rivera-Espinoza and Gallardo-Navarro, 2010; Sanders and Huis Veld, 1999; Vinderola and Reinheimer, 2003). A primary reason for this is that both these genera are dominant inhabitants of their respective niches in the intestine (Lactobacillus in the small intestine and Bifidobacterium in the large intestine) and both have a long history of safe use and are considered as GRAS (generally regarded as safe). Of the lactobacilli, $L$. acidophilus is by far the most widely used probiotic as it has a long history of research and use. As L. acidophilus is one of the predominant organisms in the intestinal tract of breastfed babies, it quickly took the place of L. bulgaricus as the probiotic of choice in the U.S. (O'Sullivan 2006). It, therefore, has almost 100 years of use in human diets. Of the bifidobacteria, B. longum is particularly dominant in human intestines (Perdigon et al., 2003), It is a highly recommend Bifidobacterium species in commercial human probiotics (Sanders, 2006). Bifidobacterium lactis (Bifidobacterium animalis ssp. lactis) is a very commonly used probiotic, although it is not a normal human inhabitant. It was first isolated in 1997 from fermented milk by Meile et al. (1997) and was noted to have a higher tolerance to oxygen and other detrimental environmental conditions (generally, higher adaptation to food conditions) than other bifidobacteria (Cai et al., 2000; Ventura and Zink, 2002). The changes that occurred in B. lactis during its adaptation to fermentation conditions make it a very resilient strain that can remain viable during processing and storage longer than other bifidobacteria. Mentioned practical reasons contribute to its popularity. These adaptations, however, would not give it a competitive edge in the intestine as the most competitive strains lose unwanted traits in a natural environment. Although this would limit the full potential of B. lactis, it still has the potential for many positives during its transient passage through the intestine (O'Sullivan, 2006).

While emphasizing the importance of strain-specificity of technological attributes of probiotics, some generalizations can still be made on the robustness of probiotic organisms. Generally, lactobacilli are more robust than bifidobacteria (Erkkilä et al., 2001; Mättö et al., 2006; Ross et al., 2005). There is a wider range of probiotic Lactobacillus species that are technologically suitable for food applications than bifidobacteria (Lee and Salminen, 2009). They are resistant to low $\mathrm{pH}$, have native association with traditional fermented foods, and have adaptation to milk and other food substrates.

A significant proportion of the commercialized probiotic bacterial species was originally selected on the basis of their technological stability (e.g., viability during food processing and storage), survival during intestinal transit, and health benefits on consumers. Good probiotic strains have demonstrated health and safety data from randomized, controlled clinical trials (Lee and Salminen, 2009; Ventura and Perozzi, 2011). 


\section{Viability of probiotics in food products}

Improving the viability of probiotic bacteria in different food products (especially fermented products) until the time of consumption has been the subject of hundreds of studies. Viability of probiotic microorganisms, namely, the number of viable and active cells per g or $\mathrm{mL}$ of probiotic food products at the moment of consumption is the most critical value of these products, because determines their medicinal efficacy (Khorbekandi et al., 2011; Tamime et al., 2005). Therefore, in order to maintain consumer confidence in probiotic products, it is important to ensure a high survival rate of the bacteria during the production of product as well as over the product shelf life (Saxelin et al., 1999). Although there is no world-wide agreement on the minimum of viable probiotic cells per gram or milliliter of probiotic product, generally, the concentrations of $10^{6}$ and $10^{7}-10^{8} \mathrm{cfu} \mathrm{mL}^{-1}$ (cfu $\mathrm{g}^{-1}$ ), respectively, have been accepted as the minimum and satisfactory levels. It has also stated that probiotic products should be consumed regularly with an approximate amount of $100 \mathrm{~g}$ $\mathrm{d}^{-1}$ in order to deliver about $10^{9}$ viable cells into the intestine (Karimi et al., 2011; Mohammadi et al., 2011; Vinderola et al., 2000a).

In order to have a positive effect in the intestinal tract some specific requirements regarding food products should be fulfilled. First, probiotics need to resist the manufacturing process; second, they should remain viable during the storage period in the commercial products until the end of the shelf-life. Many factors influence the viability of probiotic microorganisms in food products during production and storage periods. The main mentioned factors are: $\mathrm{pH}$, titrable acidity, molecular oxygen, redox potential, hydrogen peroxide, bacteriocins, short chain fatty acids, flavoring agents, microbial competitions, packaging materials and packaging conditions, rate and proportion of inoculation, stepwise/stage-wise fermentation, micro-encapsulation, milk solid non-fat content, supplementation of milk with nutrients, heat treatment of milk, incubation temperature, storage temperature, carbonation, addition of salt, sugar and sweeteners, cooling rate of the product and scale of production. Figure 2 implies main factors affecting viability of probiotics in food products. These factors are discussed below:

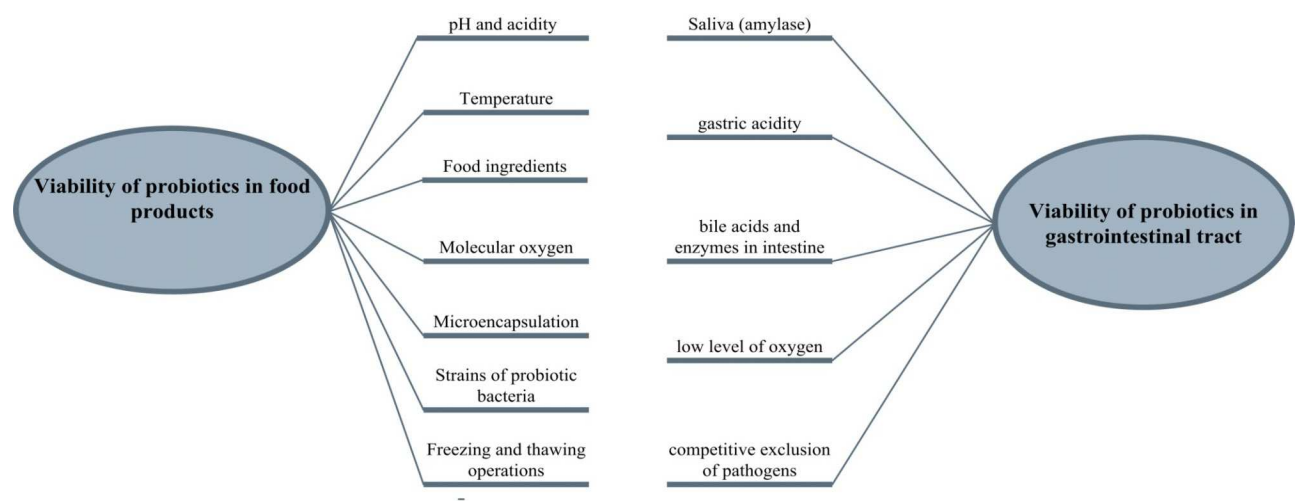

Fig. 2. Main factors affecting the viability of probiotic food products and during delivery through gastrointestinal tract. 


\subsection{Strains of probiotic bacteria}

Care must be taken in selecting the most appropriate strain for a particular food application. Indeed, the first step in incorporating a probiotic into a food is identifying compatibilities between the attributes of the selected strains and the food production steps, food matrix and storage conditions. Selection of probiotic strains used in food products should be according to both the criteria of compatibility with and resistance to the product and in vivo conditions in order to increase the viability of the probiotic bacterial strains (Korbekandi et al., 2011). The tolerance of probiotics both to the product and to the internal conditions of the living consumer is strain-dependent (strain-specific). Suitable probiotic strains are those enable to maintain their survival and stability during commercial production of products as well as during the storage period (Godward et al., 2000; Talwalker and Kailasapathy, 2004). Furthermore, high viable survival rate during delivery through the gastrointestinal tract is necessary to allow enough live cell arrival to the human intestine. Therefore, selection of resistant probiotic strains against production, storage and gastrointestinal tract condition is of prime importance. Researchers have indicated that the survival of bacteria against harsh conditions in food products such as $\mathrm{pH}$, titrable acidity, oxygen toxicity, freezing and low temperatures and storage temperatures are species- and strain-specific (Godward et al., 2000; Kailasapathy and Sultana, 2003; Ravula and Shah, 1998; Takahashi et al., 2007; Tamim et al., 2005).

Selected probiotic strains should also results in adequate sensory characteristics of final product. Some studies have shown that flavor is the first indicator with respect to the choice of a food, followed by considerations with respect to health (Mohammadi and mortazavian, 2011; Tuorila and Cardello, 2002). Consumers are not interested in consuming a functional food if the added ingredients confer disagreeable flavors on the product, even if this results in advantages with respect to their health. Therefore, a pleasant aroma and taste profiles are of importance in the formulation of probiotic functional foods and is strain-dependent. The metabolism of the probiotic cultures can result in the production of components that may contribute negatively to the taste and aroma of the product, such as acetic acid produced by Bifidobacterium spp. during fermentation and over storage period. Figure 3 shows main criteria for selection of probiotic strains in food products.

\section{$4.2 \mathrm{pH}$ and titrable acidity}

$\mathrm{pH}$ and titrable acidity of probiotic products considerably affect cell survival of probiotic microorganisms (Mortazavian et al., 2010). Low $\mathrm{pH}$ is of the most important factor that restricts the growth and stability of probiotic bacteria in fermented products. Hydrogen ions damage probiotic cells via disrupting mass transfer through the cell membranes and acidic starvation of the cells (Mortazavianand and Sohrabvandi, 2006). Very low $\mathrm{pH}$ ranges in fermented milks might cause an increase in the concentration of undissociated organic acids in them and, as a result, enhances the bacteriocidal effect of these acids. The aforementioned effect of organic acids arises from their lipophilic nature. They can be transferred through the microbial cells and dissociate within them, changing the intracellular $\mathrm{pH}$. Also, organic acids might bind to various intracellular compounds. Both of these phenomena disturb cell metabolism (Korbekandi et al., 2011).

The optimum $\mathrm{pH}$ for growth of Lactobacillus acidophilus is 5.5-6.0, but for bifidobacteria this range is $6.0-7.0$ (De Vuyst, 2000). In food products, lactobacilli are able to grow and survive 


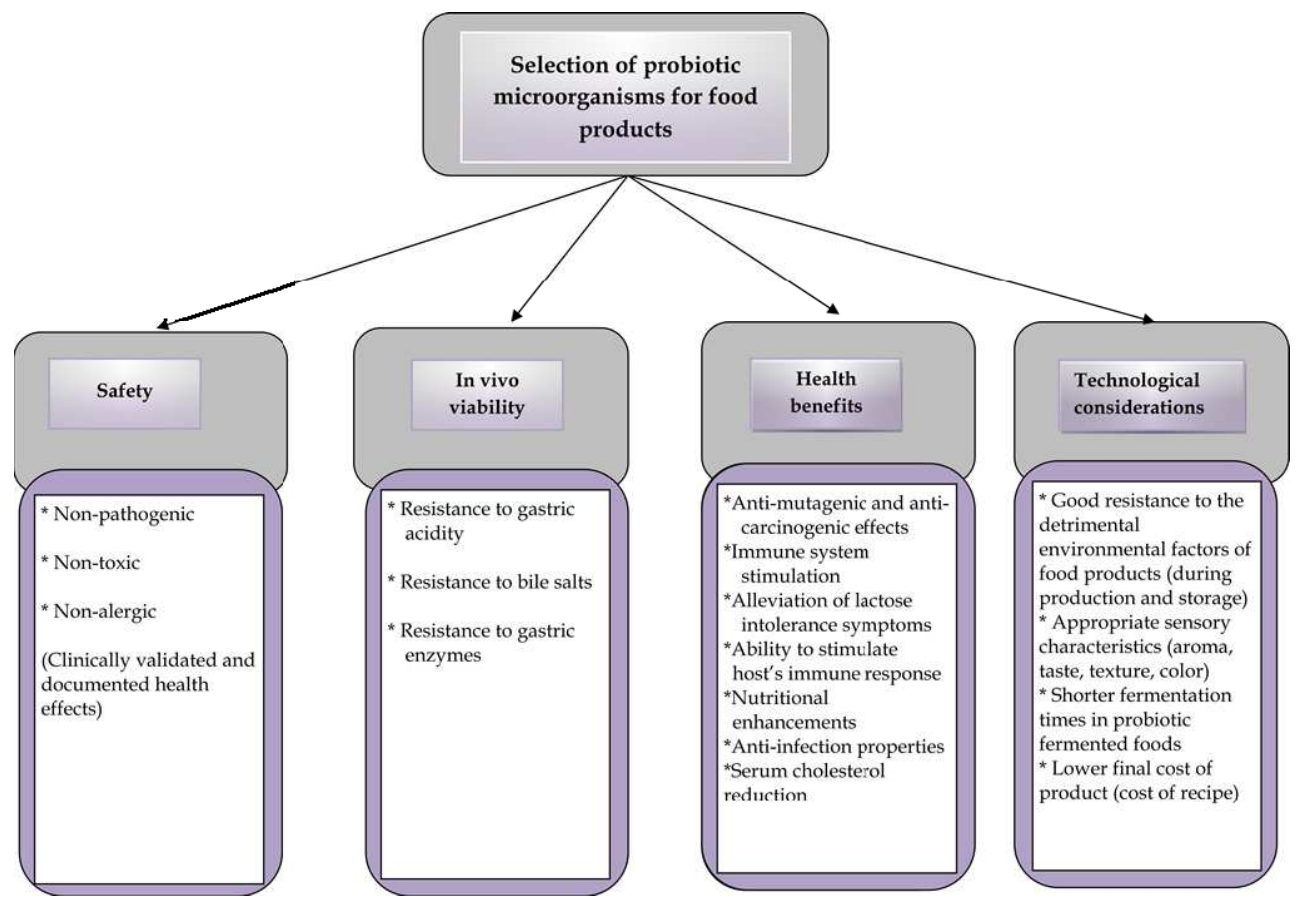

Fig. 3. Main criteria for selection of probiotic strains in food products.

in fermented milks and yogurts with $\mathrm{pH}$ values between 3.7 and 4.3 (Boylston, 2004). Bifidobacteria tend to be less acid tolerant, with most species surviving poorly in fermented products at pH levels below 4.6 (Boylston, 2004; Lee and Salminen, 2009; Ross et al., 2005). The tolerance of Bifidobacterium spp. to acidic conditions is strain-specific. The best survivability of bifidobacteria have been observed in B. longum in the presence of acidic conditions and bile salts, and for B. lactis (B. animalis ssp. lactis) in fermented milks conditions (korbekandi et al., 201; Tamim et al., 2005).

Survival in low $\mathrm{pH}$ beverages such as fruit juices $(\mathrm{pH} 3.5-4.5)$ possesses a significant challenge to probiotic survival. Researchers have reported that cell viability depends of the strains used, the characteristics of the substrate, the oxygen content and the final acidity and the concentration of lactic acid and acetic acid of the product (Shah, 2001). According to Sheehan et al., (2007), when adding Lactobacillus and Bifidobacterium orange, pineapple and cranberry juice, extensive differences regarding their acid resistance were observed. All of the strains screened survived for longer in orange and pineapple juice compared to cranberry. L. casei, L. rhamnosus and L. paracasei display a great robustness surviving at levels above $7.0 \log \mathrm{cfu} / \mathrm{ml}$ in orange juice and above $6.0 \mathrm{log} \mathrm{cfu} \mathrm{ml}-1$ in pineapple juice for at least 12 weeks (Rivera-Espinoza and Gallardo-Navarro, 2010).

\subsection{Molecular oxygen}

Lactobacilli are aerotolerant or anaerobic, and strictly fermentative, while bifidobacteria are strictly anaerobic and saccharoclastic (Holzapfel et al., 2001; De Vuyst, 2000). Therefore, 
molecular oxygen is detrimental to probiotic growth and survival. However, the degree of oxygen sensitivity varies considerably between different species and strains (Kawasaki et al., 2006). In general, lactobacilli, which are mostly microaerophilic, are more tolerant of oxygen than bifidobacteria, to the point where oxygen levels are rarely an important consideration in maintaining the survival of lactobacilli (Lee and Salminen, 2009). Oxygen content and redox potential have been shown to be important factors for the viability of bifidobacteria especially during the storage period. Oxygen affects probiotic cultures in three ways. Firstly, it is directly toxic to some cells; secondly, in the presence of oxygen, certain cultures, especially L. delbrueckii ssp. bulgaricus produces peroxide (especially in dairy products), which is toxic to probiotic cells particularly L. acidophilus; and thirdly, free radicals produced from the oxidation of components (e.g., fats) are toxic to probiotic cells (Korbekandi et al., 2011; Tamim et al., 2005).

Several methods have been used to decrease oxygen content. The most important ones are accomplishing fermentation under vacuum (for fermented products), using vacuum packaging, using packaging materials with low permeability to oxygen, adding antioxidants and oxygen scavengers to milk (such as ascorbic acid), and controlling the production process in such a way that minimum dissolved oxygen entered into product (Dave and Shah 1997; Korbekandi et al 2011; Shah, 2000; Talwalkar and Kailasapathy, 2003; Talwalkar et al., 2004).

\subsection{Food ingredients}

The compatibility of probiotics with other ingredients within food formulations can have a significant impact on bacterial survival. Interactions between probiotics and other ingredients can be protective, neutral, or detrimental to probiotic stability (Lee and Salminen, 2009; Mattila-Sandholm et al., 2002). The main affective food ingredients are mentioned as follows:

\subsubsection{Food additives}

Food additives used in the food industry could significantly affect the growth and viability of probiotic bacteria (e.g. L. acidophilus, L. casei, L. paracasei, L. rhamnosus and bifidobacteria) and starter cultures (e.g. S. thermophilus, L. delbrueckii ssp. Bulgaricus, Lactococcus lactis and Saccharomyces spp.) used for fermented and nonfermented products (Vinderola et al., 2002). These additives include salts $(\mathrm{NaCl}$ and $\mathrm{KCl}$ ), sugars (sucrose and lactose), sweeteners (acesulfame and aspartame), aroma compounds (diacetyl, acetaldehyde and acetoin), natural colorings for fermented milks (red, yellow and orange colorings), flavoring agents (strawberry, vanilla, peach and banana essences), flavoring-coloring agents (strawberry, vanilla and peach), nisin (a polypeptide-type antibiotic produced by L. lactis which is active against spore- forming bacteria and could be used as a natural preservative in addition to lactic acid), natamycin, lysozyme and nitrate (Vinderola et al., 2002). Elevated levels of ingredients can inhibit probiotics during storage (Arihara et al., 1998; Boylston et al., 2004; Kourkoutas et al., 2006; Lee and Salminen, 2009).

\subsubsection{Growth and protective factors}

Probiotic lactobacilli and, in particular, bifidobacteria grow poorly in milk due to lack of non-protein nitrogen (free amino acids and small peptides) and some vitamins, as well as to 
their slow activity of $\beta$-galactosidase (Korbekandi et al., 2011). A good and common method to compensate for slow growth is to fortify milk with different growth factors (consumed by probiotics as nutrients) and/or growth promoters (which improve viability of probiotics but not as a direct nutrient) such as casein, whey protein hydrolysates, $L$-cysteine, yeast extract, glucose, vitamins, minerals and antioxidant. These supplements have significant positive effects on the survival of probiotic microorganisms (Mohammadi et al., 2011).

The addition of $L$-cysteine, whey protein concentrate, acid casein hydrolysate and tryptone improved the viability of L. acidophilus and bifidobacteria by providing growth factors as these probiotic bacteria lack proteolytic activity (Dave and Shah, 1998). Protein derivatives promote probiotic survival due to several reasons; namely, their nutritional value for the cells, reducing redox potential of the media as well as increasing buffering capacity of the media (which results in a smaller decrease in $\mathrm{pH}$ ) (Dave and Shah, 1998; Mortazavian et al., 2010). It should be pointed out that effects of milk proteins on the viability of probiotics depends on various factors such as the type of the strains used, specifications of the milk protein derivative added, inoculation conditions and formulation of the product. It has been reported that casein and whey protein hydrolysate enhanced the acidification rate of $S$. thermophilus and reduced the growth rate of probiotic organisms (L. acidophilus La-5 and L. rhamnosus Lr-35) in fermented milks during the manufacturing stages, although the survival of the latter bacteria was improved after storage (Lucas et al., 2004).

Prebiotics are non-viable and non-digestible (or minimally digestible) food ingredients which are metabolized selectively by beneficial intestinal bacteria and enhance their growth and/or activity. They are mostly sugar-like compounds (oligosaccharides) comprising between two and ten monomers that largely resist digestion by pancreatic and brush border enzymes. The term "synbiotic" is used to describe products that contain both probiotics and prebiotics (Nobakhti et al., 2009). These compounds (such as fructooligosaccharides and galactooligosaccharides) can have suitable effect on retention of probiotics viability (especially bifidobacteria) in food products as well as in gastrointestinal tract (Gibson et al., 2004; Mizota, 1996; Mohammadi et al., 2011; Rycroft, 2001).

The food matrix, itself, can be protective. An example is cheese, where the anaerobic environment, high fat content and buffering capacity of the matrix helps to protect the probiotic cells both in the product and during intestinal transit (Boylston et al., 2004; Lee and Salminen, 2009). In contrast to liquid foods, the solid matrices in food products, such as the gel structure in yogurt or cheese, support probiotic cells by reducing their exposure to detrimental factors (e.g., hydrogen ions and organic acids) (Karimi et al., 2011; Mohammadi and Mortazavian, 2011). These matrices can act as a barrier (by physically and chemically binding hydrogen ions and organic acids (Korbekandi et al., 2011). Increasing the buffering capacity of milk would stimulate growth and activity of probiotics in fermented milks. It leads to higher viability of probiotics in dairy fermented products as well as in the gastrointestinal tract due to the maintenance of $\mathrm{pH}$ at higher values. Also, the $\mathrm{pH}$ of the products with higher buffering capacity declines slowly during refrigerated storage and results in a greater survival of probiotic cells. Moreover, by absorbing hydrogen ions into the dry matter of product matrix (such as proteins), the amounts of undissociated organic acids are increased, resulting in the reduction of bacteriocidic effect of these compounds on probiotics (Mortazavian et al., 2011; korbekandi et al., 2011; Heydari 2011). 


\subsection{Temperature}

The temperature at which probiotic organisms grow is important in food applications where fermentation is required. Also, storage temperature exhibits considerably important role. Fermentation temperature is one of the most important factors affecting the qualitative parameters of probiotic fermented milks, including the viability of probiotic microorganisms and fermentation time (incubation time). The optimum temperature for growth of most probiotics is between $37^{\circ} \mathrm{C}$ and $43^{\circ} \mathrm{C}$ (Boylston et al., 2004; Doleyres and Lacroix 2005; Lee and Salminen, 2009). Although the growth of L. acidophilus may occur at temperatures as high as $45{ }^{\circ} \mathrm{C}$, the optimum growth occurs within $40-42^{\circ} \mathrm{C}$. The optimum growth temperature for bifidobacteria is $37-41^{\circ} \mathrm{C}$ (Korbekandi et al., 2011). Species of bifidobacteria isolated from the human intestinal tract such as B. longum (infantis), B. breve, B. bifidum, and $B$. adolescentis have optimum growth temperatures in the range of $36-38^{\circ} \mathrm{C}$, whereas $B$. animalis ssp. lactis can grow at higher temperatures of $41-43^{\circ} \mathrm{C}$ (Crittenden, 2004; Doleyres and Lacroix 2005; Lee and Salminen, 2009).

Temperature is also a critical factor influencing probiotic survival during storage period. Probiotic food products usually, should be stored at a refrigerated temperature, preferably $4-5^{\circ} \mathrm{C}$. The storage temperature of probiotic food products affects the viability of the probiotics via effects of temperature on the cells survival, the type and concentration of metabolites formed between starter bacteria and probiotics in fermented products. Mortazavian et al. (2007a) found that storage in ABY-type culture (L.acidophilus, $B$. lactis and yogurt bacteria) at $2^{\circ} \mathrm{C}$ for 20 days resulted in the highest viability of $L$. acidophilus LA-5, whereas, for Bifidobacterium lactis BB-12, the highest viability was obtained when yogurt was stored at $8^{\circ} \mathrm{C}$ (Mortazavian et al., 2007b). Low resistance of bifidobacteria cells to low refrigeration temperatures $\left(2^{\circ} \mathrm{C}\right.$ or less) has been proven (Kailasapathy and Rybka, 1997; Korbekandi et al., 2011). In general, in ABY-type culture, storage of the product at $4-5^{\circ} \mathrm{C}$ appears to result in greatest viability of both probiotics, i.e., L. acidophilus and bifidobacteria (Mortazavian et al., 2008). During processing, temperatures above $45-50^{\circ} \mathrm{C}$ will be detrimental to probiotic survival. The higher the temperature, the shorter the time period of exposure required to severely decrease the numbers of viable bacteria, ranging from hours or minutes at $45-55^{\circ} \mathrm{C}$ to seconds at higher temperatures. It is obvious that probiotics should be added downstream of heating/cooking/pasteurization processes in food manufacture (Lee and Salminen, 2009). Freezing temperatures can also affect viability of probiotics. This is discussed in the next section.

\subsection{Freezing and thawing operations}

Probiotics can survive well over long shelf lives in products such as frozen yogurts and ice cream. During the freezing process, the cells of probiotics can be lethally injured by damaging their cell walls or their cell membranes caused by mechanical stresses of the ice crystals formed in the external medium or inside the cells, by temperature decrease chock to the cells and cold injuries, by condensation of solutes (those are detrimental to probiotic cells) in the extracellular/intracellular media, or by dehydration of the cells. All mentioned factors cause reduction or interruption of vital metabolic activities of the cells that are necessary for their live (Akin et al., 2007; Davies and Obafemi, 1985; Gill 2006; Jay et al., 2005). The size of the ice crystals increases with decrease in freezing rate and larger 
intracellular ice crystals causes greater damage to the cells (Gill, 2006; Jay et al., 2005). Therefore, rapid freezing after inoculating with the probiotic microorganisms contributes to the good maintenance of the populations of these microorganisms in the product (Mohammadi et al., 2011).

Probiotic cells are subjected to some chemical stresses during melting (freeze-thaw) of the frozen products which can cause mortality to them. On one hand, the cells are exposed to osmotic effects (Jay et al., 2005). On the other hand, the high concentrations of detrimental factors such as hydrogen ions, organic acids, oxygen and other poisoning components to probiotic cells in melting media, associated with freezing concentration, are the factors having a great effect on viability loss of probiotics. $\mathrm{pH}$ has been found to exhibit a crucial role in this regard.

\subsection{Drying process}

Powdered foods have much longer shelf life at an ambient temperature. Drying can be achieved by different methods such as freeze drying, spray drying, microwave drying and vacuum drying. Spray drying could be achieved at a lower cost compared with other techniques. However, spray drying could lead to a loss of viability of the probiotic cells due to encountering them to several stresses including high temperature, dehydration, osmotic pressure, gradual increase in detrimental compounds during drying and mechanical stress (shearing). Also, concentration of dissolved oxygen might also increase in dried products which could be toxic to bifidobacteria (Korbekandi et al 2011; Rybka and Kailasapathy, 1997). In the spray drying method, the most critical parameters affecting survival of bifidobacteria are the type of atomization, air pressure, and the outlet temperature (Champagne and Møllgaard, 2008). Freeze drying is the best process for maintaining the viability of the bacterial cells used for preparing starter culture cells. However, its costeffectiveness should be evaluated before usage.

\subsection{Microencapsulation}

Microencapsulation, as one of the new and efficient methods, has recently been under especial consideration and investigation. From microbiological point of view, microencapsulation can be defined as the process of entrapment/enclosure of microorganisms cells by means of coating them with proper hydrocolloid(s) in order to segregate the cells from the surrounding environment; in a way that results in appropriate cell release in the intestinal medium (Krasaekoopt et al., 2003; Mortazavian et al., 2007b, 2008; Picot and Lacroix, 2003; Sultana et al., 2000). Microencapsulation of probiotic cells has been shown to preserve them from detrimental environmental factors such as low $\mathrm{pH}$ and high acidity (Wenrong and Griffiths, 2000), bile salts (Lee and Heo, 2000), cold shocks induced by the process conditions such as deep freezing and freeze drying (Shah and Rarvula, 2000), molecular oxygen in case of obligatory anaerobic microorganisms (Sunohara et al., 1995), heat shocks caused by process conditions such as spray drying, bacteriophages (Steenson et al., 1987) and chemical antimicrobial agents (Sultana et al., 2000). In addition, other advantages such as increase improvement and stabilization of sensory properties (Gomes and Malcata, 1999) and immobilization of the cells for their homogeneous distribution throughout the product (Krasaekoopt et al., 2003) can also be achieved by this process. 
This process has been recently used as an efficient method for improving the viability of probiotic bacteria in fermented milk drinks, fermented frozen dairy desserts, ice cream and juices (Adhikari et al., 2000; Krasaekoopt et al., 2004; 2005; Kailasapathy, 2006; Mohammadi et al., 2011), and simulated gastrointestinal tract (Hansen et al., 2002; Korbekandi et al., 2011; Lee and Heo, 2000; Krasaekoopt et al., 2004; Mortazavian et al., 2008; Sultana et al., 2000; Wenrong and Griffiths, 2000). Encapsulated probiotic organisms, when incorporated into fermented frozen dairy desserts, showed an improved viability of $>10^{5} \mathrm{cfu} \mathrm{g}^{-1}$ in the product compared to counts of $<10^{3} \mathrm{cfu}^{-1}$ when non-encapsulated organisms were used (Mortazavian et al., 2010 ; Shah and Ravula 2004). Studies suggest that, micro-encapsulation of free probiotic cells can increase their viability by $\geq 2$ log cycles in fermented milks during a refrigerated storage period. As mentioned earlier, in fermented milk drinks with $\mathrm{pH}$ values of less than 4.2 , free cells of L. acidophilus LA-5 lost their viability to less than $10^{6} \mathrm{cfu}$ $\mathrm{mL}^{-1}$ after 1 week; and in the case of Bifidobacterium lactis BB-12, a similar loss occurred after 2 weeks of storage. For encapsulated cells, viable population of L. acidophilus and bifidobacteria remained higher than $10^{5}$ and $10^{6} \mathrm{cfu} \mathrm{mL}^{-1}$ after 42 days of refrigerated storage, and counts of free probiotic free cells were not detected and $10^{2} \mathrm{cfu} \mathrm{mL}-1$, respectively (Mortazavian et al., 2008).

\subsection{Packaging materials and conditions}

The packaging of probiotic food products influences the oxygen permeability into the product, and as a result, affects the viability of bifidobacteria, L. acidophilus and other probiotic species during the storage period. Several aspects of food packaging materials including the type of the packaging materials (Glass and plastic) their thickness, and the application of active/intelligent packaging systems could influence survival of probiotic bacteria (Korbekandi et al., 2011). In general, two important points are worth mentioning. Firstly, apart from the packaging materials, the temperature and relative humidity of the atmosphere are the key factors affecting oxygen permeability. Secondly, besides the efficiency of packaging, the economic aspect should also be taken into account (the price of packaging materials as well as the price of packaging machines) because they can significantly influence the final price of products and their sale volumes.

\section{Viability of probiotics in food products during delivery through gastrointestinal tract}

The gastrointestinal tract (GIT) with its diverse and concentrated microbial population (at birth $10^{14} \mathrm{cfu} \mathrm{g}^{-1}$ and between 400 and 500 species) is one of the key organs of the human body, and it is in fact an ecosystem of highest complexity that mediates numerous interactions with the chemical (and nutritional) environment. The gastrointestinal tract starts in mouth, travels through the stomach, intestines and ends at the anus. In each section of the gastrointestinal tract, different types and quantities of microbes are found. The average adult carries about four pounds of microbes in their intestinal tract (Tannis, 2008). Nonetheless, diversity at a division level is among the lowest (Bäckhead et al., 2005) and the lactobacilli and bifidobacteria comprise less than 5\% of the total microbiota (Lay et al., 2005; Lee and Salminen, 2009).

Probiotics targeting the intestine clearly encounter the greatest hurdles in order to be delivered to their targeted site. The main factors to be considered that influence the viability 
of food-containing probiotics in GIT conditions are: 1) Food matrix, 2) very low $\mathrm{pH}$ in the stomach, 3) bile salts and gastro-enzymes in the small intestine, 4) Lysozyme in saliva, and 5) colonic environments (competitions with other microorganisms including pathogens).

The effect of food matrix on the intestinal survival of probiotic bacteria is insufficiently studied. Rochet et al. (2008) did not see any difference in the faecal level of B. animalis strain, when $6 \times 10^{10}-2 \times 10^{11} \mathrm{cfu} \mathrm{g}^{-1}$ were administered in fermented milk or in freeze-dried form, but the food matrix improved significantly the survival of L. plantarum MF1298 (Klingberg and Budde, 2006) and L. rhamnosus GG (Saxelin et al., 1993), when lower doses $\left(6 \times 10^{9} \mathrm{cfu}\right.$ and $1-2 \times 10^{9} \mathrm{cfu}$, respectively) were used (Saxelin et al., 2010). Fresh dairy products are the most common product forms of probiotic delivery, but ripened cheeses have also been successfully tested as a carrier matrix. Data from Saxelin et al. (2003) showed an increased recovery of L. rhamnosus in human stools resulting from the following delivery matrices: powder<juice or fermented milk<unfermented milk<cheese. The appropriate protecting effect of cheese matrix toward probitic cells can be attributed to its dense matrix, high buffering capacity and relatively high fat content (Gardiner et al., 1999; Karimi et al., 2011). The buffering ability of the food matrix is arguably a critical factor. But the presence of a fermentable carbohydrate also improves a culture's ability to survive a simulated gastric environment (Corcoran et al., 2005). In this regard, the carbohydrate provides the cell with the ability to produce ATP, which is required for pumping out acid from the cytoplasm. Not surprisingly, the fibre/carbohydrate content of the food matrix strongly affects the stability of probiotic bacteria during storage in a fruit juice (Saarela et al., 2006; Farnworth and Champagne, 2010).

Among the hurdles and stressful conditions against safe transition of probiotic cells to the intestine, harsh acid conditions in stomach and the bile substances in the duodenum (The first part of the small intestine) are the most important (Lee and Salminen, 2009). The first barrier that bacteria must overcome is the very low $\mathrm{pH}$ values of the stomach with values ranging from 1 to 3 and mean exposure times of $90 \mathrm{~min}$. Into the duodenum the $\mathrm{pH}$ value rises to $6-6.5$, but bile salts are poured from the gallbladder to reach concentrations ranging from 1.5 to $2 \%$ during the first hour of digestion and decreasing afterwards to $0.3 \% \mathrm{w} / \mathrm{v}$ or lower (Noriega et al., 2004). The residence period in the small intestine until 50\% emptying oscillate between 2.5 and $3 \mathrm{~h}$ and the transit through the colon could take up to $40 \mathrm{~h}$ (Camilleri et al., 1989). Even when product formulation procedures that ensure viability during production and storage have been used as described above, the live bacteria must survive transit of the upper GIT. Ethics, cost, and complexity of tests prevent the testing of foods containing probiotics using human feeding trials. In vitro tests, using models of the GIT, can be used to provide data about the ability of bacteria to survive the harsh conditions of the upper GIT. Several $\mathrm{pH}$ values and bile concentrations are tested for variable times in order to determine the survival of the strain(s) under test. Many studies that have used testtube experiments to simulate the acidic conditions in the stomach, and exposure to bile salts and digestive enzymes that occur in the small intestine have been reported (Boza et al., 2004; Horaczek and Viernstein, 2004; Farnworth and Champagne, 2010; Pascual et al., 1999). De Smet et al., (1995) indicated that a concentration of $0.3 \%$ bile salts is critical for the screening of human probiotics, and this ability was associated to the presence of bile salt hydrolase activity. Nevertheless, Schmidt et al., (2001) showed that at least in lactobacilli, bile salt resistance could not be correlated to the presence of this enzyme. The study performed by Floch et al. (1972) indicated that conjugated bile acids are less inhibitory than free bile acids 
(cholic and deoxycholic) toward intestinal aerobic and anaerobic bacteria (Rivera-Espinoza and Gallardo-Navarro, 2010). The results of viability obtained are strain dependent and, in general, bifidobacteria strains are less tolerant to acidic conditions than lactobacilli, whereas the first seems to be more tolerant to bile challenge (Lee and Salminen, 2009). The recovered strains were intrinsically resistant to acid gastric conditions ( $\mathrm{pH} 2.0)$ and also showed good tolerance to high concentrations of bile salts and $\mathrm{NaCl}$. This cross-resistance between low $\mathrm{pH}$ and bile salts was previously described in bile-adapted strains (Noriega et al 2004). It is known that exposure to one stress can induce a response that protects cells against multiple stresses (Duwat et al 2000). As the stress response is already induced at that stage, it may be capable of surviving the bile in the duodenum. This is pertinent as many candidate isolates may be overlooked if they do not display direct resistance to bile, when in reality the ability to induce sufficient tolerance is all that is required (O'Sullivan, 2006).

The development of intestinal microbiota is of major importance for the health of newborns. Especially lysozyme present in human milk may affect colonization of newborn intestinal tract by specific bifidobacterial strains. Lysozyme is an antimicrobial enzyme (EC 3.2.1.17) found in tears, saliva, human milk, mucus, neutrophil granules and egg white (Field, 2005). It hydrolyses the $\beta-(1,4)$ linkage between $\mathrm{N}$-acetylglucosamine and $\mathrm{N}$-acetylmuramic acid in bacterial cell wall and Gram-positive bacteria are more susceptible to lysozyme than Gramnegative bacteria. The effect of saliva on the intestinal survival of probiotic bacteria is insufficiently studied. The resistance to lysozyme at $25-35 \mathrm{mg} \mathrm{L}^{-1}$ was recommended as a criterion for the selection of a lactic acid bacterial strain suitable for use in milk industry (Guglielmonti et al., 2007). The resistance to lysozyme at $25-35 \mathrm{mg} \mathrm{L}^{-1}$ was recommended as a criterion for the selection of a lactic acid bacterial strain suitable for use in milk industry (Guglielmonti et al., 2007). According to findings, the tolerance of probiotics to lysozyme is strain-dependent (Rada et al., 2010). Bifidobacteria naturally occur within the whole intestinal tract from oral cavity to large intestine. Lysozyme is naturally present in saliva and other biological fluids (tear fluid). Hence, the interaction of inhabitant bifidobacteria or bifidobacteria-containing food products and lysozyme is inevitably occurred. The salivary lysozyme may also interact with other probiotic bacteria and can vary from 17 to $181 \mu \mathrm{g} \mathrm{mL}$ 1 (Koh et al., 2004). Some bifidobacteria seems to be also completely lysozyme-resistant (Rada et al., 2010). Therefore, being resistance to lysozyme is a criterion for the selection of new probiotic bifidobacterial strains. Figure 3 represents main factors affecting viability of probiotics during transition through the GIT.

\section{Conclusion}

Probiotic functional foods, one of the largest markets of functional foods, represent a huge growth potential for the food industry and may be explored through the development of innovative ingredients, processes, and products. Therefore, the process of producing and manufacturing probiotic functional foods should have standardized protocols and quality control procedures. Safety and functional efficiency of the probiotic food products in the body and technological characteristics (viability, sensory properties, economic aspects and physicochemical and rheological characteristics) has been under special attention in recent years and many achievements in mentioned aspects have been attained. To provide health benefits related to probiotic organisms, maintaining viable counts of each probiotic strain in gram or milliliter of probiotic products above a minimum standard level (e.g., $10^{6} \mathrm{cfu} \mathrm{mL}^{-1}$ ) 
until the time of consumption is quite important. Adding probiotics to food products holds many challenges, such as biorelationships among the starter bacteria, $\mathrm{pH}$, organic acids, molecular oxygen, freezing and thawing operations, additives such as sodium chloride, sugar, anti-microbial preservatives. Therefore, a wide range of research has been focused on optimization of formulation and processing as well as packaging of probiotic food products in order to increase the viability of probiotic cells in them until the time of consumption. However, a high viable population of probiotic bacteria in food products at the time of consumption does not guarantee the same survival rate after the arrival of the cells in the intestine. Probiotics targeting the intestine clearly encounter the greatest hurdles in order to be delivered to their targeted site. The biggest hurdles are the acid conditions of the stomach, the bile in the duodenum and competitive exclusion of pathogens. Therefore, clinical studies as well as simulated gastrointestinal tract investigations, should be integrated to the technological research.

\section{References}

Adhikari, K; Mustapha, A; Grun, I. U. \& Fernando, L. (2000). Viability of microencapsulated bifidobacteria in set yogurt during refrigerated storage. J Dairy Sci 83: 1946-1951

Akalin. A.S. and D. Erisir (2008). Effects of inulin and oligofructose on the rheological characteristics and probiotic culture survival in low-fat probiotic ice cream. J Food Sci 73:184-188.

Akin. M. B., M. S. Akin and Z. Kirmaci (2007). Effects of inulin and sugar levels on the viability of yogurt and probiotic bacteria and the physical and sensory characteristics in probiotic ice cream. Food Chem 104:93-99

Amiri, Z. R., P. Khandelwal, B. R. Aruna and N. Sahebjamnia (2008). Optimization of process parameters for preparation of synbiotic acidophilus milk via selected probiotics and prebiotics using artificial neural network. J Biotechnol 136:460

Andersson, H., N.G. Asp, A. Bruce, S. Roos, T. Wadstrom and A. E. Wold (2001). Health effects of probiotics and prebiotics. A literature review on human studies. Scand J Nutr/Naringsforskning 45: 58-75

Angelov, A., V. Gotcheva, R. Kuncheva and T. Hrstozova (2006). Development of a new oatbased probiotic drink. Int J Food Microbiol 112:75-80

Arihara, K., H. Ota, M. Itoh, Y. Kondo, T. Sameshima, H. Yamanaka, M. Akimoto, S. Kanai and T. Miki (1998). Lactobacillus acidophilus group lactic acid bacteria applied to meat fermentation. J. Food Sci 63: 544-547.

Aryana, K. J. and P. Mcgrew (2007). Quality attributes of yogurt with Lactobacillus casei and various prebiotics. LWT-Food Sci Technol 40:1808-14

Bäckhead, F., R. E. Ley, J. L. Sonnenburg, D. A. Peterson and J.I. Gordon (2005). Hostbacterial mutualism in the human intestine. Science 307: 1915-1919

Betoret, N., L. Puente, M. J. Diaz, M. J. Pagan, M. J. Garcia and M. L. Gras (2003). Development of probioticenriched dried fruits by vacuum impregnation. J Food Engr 56:273-277

Blanchette, L., D. Roy. G. Belanger and S. F. Gauthier (1996). Production of cottage cheese using dressing fermented by bifidobacteria. J Dairy Sci 79:8-15

Blandino, A., M. E. Al-Aseeri, S. S. Pandiella, D. Cantero and C. Webb (2003). Review: Cereal-based fermented foods and beverages. Food Res Int 36: 527-543. 
Blandino, A., M. E. Al-Aseeri, S.S. Pandiella, D. Cantero and C Webb (2003). Cereal-based fermented foods and beverages. Food Res Int 36:527-43

Boylston, T. D., C. G. Vinderola, H. B. Ghoddusi and J. A. Reinheimer (2004) Incorporation of bifidobacteria into cheeses: challenges and rewards. Int Dairy J 14: 375-387

Boza, Y., D. Barbi and A. R. P. Scamparini (2004). Survival of Beijerinckia sp. microencapsulated in carbohydrates by spray-drying. J Microencapsul 21: 15-24

Cai, Y. M., M. Matsumoto, and Y Benno. (2000). Bifidobacterium lactis is a subjective synonym of Bifidobacterium animalis (Mitsuoka 1969; Scardovi and Trovatelli 1974). Microbiol Immunol 44: 815-820

Camilleri, M., L. J. Colemont, S. F. Phillips, M. L. Brown, G. M. Thomforde, N. Chapman, and A. R. Zinsmeister (1989). Human gastric emptying and colonic filling of solids characterized by a new method. Am. J. Physiol. Gastrointest. Liver Physiol 257: 284-290

Cargill. 2009. Cargill beverage concepts will address consumer demands for health, taste and texture at IFT 2008. Available from: http://www.cargill.com/newscenter/news-releases/ 2008/NA3007612.jsp. Accessed Jul 20, 2009.

Champagne, C. P and H. Møllgaard (2008). Production of Probiotic Cultures and Their Addition in Fermented Foods. In R. F. Edward (Eds.), Handbook of Fermented Functional Foods (2 edition). United States of America: CRC Press, Taylor \& Francis Group.

Chen, I. N. C. C., C. Y. Wang and T. L. Chang (2008). Lactic fermentation and antioxidant activity of Zingiberaceae plants in Taiwan. Int J Food Sci Nutr 22:1-10

Corbo, M. R., M. Albenzio, M. De Angelis, A. Sevi and M. Gobbetti (2001). Microbiological and biochemical properties of Canestrato Pugliese hard cheese supplemented with bifidobacteria. J Dairy Sci 84:551-61.

Corcoran, B. M., C. Stanton, G. F. Fitzgerald and R. P. Ross (2005). Survival of probiotic lactobacilli in acidic environments is enhanced in the presence of metabolizable sugars. Applied Environ Microbiol 71:3060-3067

Crittenden, R (2004). An update on probiotic Bifidobacteria. Salminen S., A. von Wright and Ouwerhand A(eds). Lactic Acid Bacteria: Microbiological and Functional Aspects. Marcel Dekker, New York, 125-157.

Dalev, D., M. Bielecka, A. Troszynska, S. Ziajka and Lamparski (2006). Sensory quality of new probiotic beverages based on cheese whey and soy preparation. Pol J Food Nutr Sci 15:65-70

Dave, R. I. and N. P. Shah (1997). Effectiveness of ascorbic acid as an oxygen scavenger in improving viability of probiotic bacteria in yoghurts made with commercial starter cultures. Int Dairy J 7: 435-43

Dave, R.I. and N.P. Shah (1998). Ingredient supplementation effects on viability of probiotic bacteria in yogurt. J Dairy Sci 81:2804-2816

Davidson, R. H., S. E. Duncan, C. R. Hackney, W. N. Eigel and J.W. Boling (2000). Probiotic culture surival and implications in fermented frozen yogurt characteristics. J Dairy Sci 83:666-73

Davies, R. and A Obafemi (1985) Response of micro-organisms to freeze-thaw stress. In: Robinson RK (ed) Microbiology of frozen foods, Elsevier Applied Science Publishers, London U.K pp, 83-107. 
De Smet, I., L.Van Hoorde, M. Van de Woestyne, H. Christiaens and W. Verstraete (1995). Significance of bile salt hydrolytic activities of lactobacilli. J Appl Bacteriol 79: 292301

De Vuyst, L. (2000). Technology Aspects Related to the Application of Functional Starter Cultures. Food Tech Biotech 38: 105-12

Diplock, A.T., P. J. Aggett, M. Ashwell, F. Bornet, E. B. Fern and M. B. Robrrfroid (1999). Scientific concepts of functional food in Europe: Consensus document. Br J Nutr 81: 11-27.

Doleyres, Y. and C. Lacroix (2005). Technologies with free and immobilised cells for probiotic bifidobacteria production and protection. Int Dairy J 15: 973-988

Donkor, O. N., A. Henriksson, T. Vasiljevic and N. P. Shah (2007) a-Galactosidase and proteolytic activities of selected probiotic and dairy cultures in fermented soymilk. Food Chem 104:10-20

Duwat, P., B. Cesselin, S. Sourice and A. Gruss (2000). Lactococcus lactis, a bacterial model for stress responses and survival. Int J Food Microbiol 55: 83-86

El-Nagar, G., G. Clowes, C. M. Tudorica and V. Kuri (2002) Rheological quality and stability of yog-ice cream with added inulin. Int J Dairy Technol 55:89-93

Erkkilä S., M. L. Suihko, S. Eerola, E. Petäjä and T. Mattila-Sandholm (2001). Dry sausage fermented by Lactobacillus rhamnosus strains. Int J Food Microbiol 64: 205-210

Farnworth E. R. and C.Champagne (2010). Production of Probiotic Cultures and Their Incorporation into Foods. In: Watson R. R and V. R. Preedy (Eds) Bioactive Foods in Promoting Health: Probiotics and Prebiotics. Elsevier, Oxford, UK. Pp 2-18

Feng, X. M., A. R. B. Eriksson and J. Schnurer (2005). Growth of lactic acid bacteria and Rhizopus oligosporus during barley tempeh. Int J Food Microbiol 104:249-256

Field, C.J (2005). The immunological components of human milk and their effect on immune development in infants. J Nutr 135:1-4

Floch, M. H., H. J. Binder, B. Filburn and W. Gershengoren (1972). The effect of bile acids on intestinal microflora. Am J Clin Nutr 25:1418-1426

Gardiner G, Ross RP, Stanton C, Lynch PB, Collins JK, Fitzgerald G (1999) Evaluation of Cheddar cheese as a food carrier for delivery of a probiotic strain to the gastrointestinal tract. J Dairy Sci 82:1379-1387

Ghoddusi, H. B. and R. K. Robinson (1996). The test of time. Dairy Indust Int 61:25-28

Gibson, G. R., B. Rabiu, C. E. Rycroft and R.A. Rastall (2004) Trans-Galactooligosaccharides as Prebiotics. In: Shortt, C., J.O. Brien (eds) Handbook of Functional Dairy Products, CRC Press LLC USA pp.91-109

Gill,C. O. (2006). Microbiology of frozen foods. In: Da-Wen Boca S (ed) Handbook of frozen food processing and packaging. CRC Press Ranton pp. 85-100

Godward, G., K .Sultana, K. Kailasapathy, P. Peiris, R. Arumugaswamy and N. Reynolds (2000) The importance of strain selection on the viability of probiotic bacteria in dairy foods. Milchwissenschaft 55:441-445

Gomes, A. M. P. and F. X. Malcata (1999). Bifidobacterium spp. and Lactobacillus acidophilus: biological, biochemical, technological and therapeutical properties relevant for use as probiotics. Trends Food Sci Technol 10:139-57

Granato, D., G. F. Branco, A. G. Cruz, J.A.F.Faria and F. Nazzaro (2010). Functional foods and nondairy probiotic food development: Trends, Concepts and products. Compr Rev Food Sci Food Saf. 9: 292-302. 
Guglielmonti, D. M., M. B. Marco, M. Golowczyc, J. A. Reinheimer andA. D. Quiberoni (2007) Probiotic potential of Lactobacillus delbrueckii strains and their phage resistant mutants. Int Dairy J 17:916-925

Hansen, L. T and P. M. Allan-Wojtas Y. L. Jin and A. T. Paulson (2002). Survival of Caalginate microencapsulated Bifidobacterium ssp. in milk and simulated gastrointestinal conditions. Food Microbiol 19: 35-45

Haynes, I.N. and M. J. Playne (2002). Survival of probiotic cultures in low-fat ice cream. Aust J Dairy Technol 57:10-14

Heenan, C. N., M. C. Adams, R. W. Hosken and G. H. Fleet (2005). Survival and sensory acceptability of probiotic microorganisms in a nonfermented frozen vegetarian dessert. Food Sci Technol 37:461-6

Helland, M. H., T. Wciklund and J. A Narvhus (2005). Growth and metabolism of selected strains of probiotic bacteria in milk- and water-based cereal puddings. Int Dairy J 14:957-65

Heydari, S., A. M. Mortazavian, M. R. Ehsani, M. A. Mohammadifar and H. Ezzatpanah (2011) Biochemical, microbiological and sensory characteristics of probiotic yogurt containing various prebiotic compounds. Ital J Food Sci 23:153-163

Holzapfel W.H. (2006). Introduction to Prebiotics and Probiotics. In: Goktepe I., V.K. Juneja, M. Ahmedna, Probiotics in Food Safety and Human Health. CRC Press,Taylor \& Francis Group, LLC. New York. US. pp 1-35

Holzapfel, W. H., P. Haberer, R. Geisen, J. Björkroth and U. Schillinger (2001). Taxonomy and important features of probiotic microorganisms in food and nutrition. Amer $\mathrm{J}$ Clinical Nutr 73:365-373

Homayouni, A., A. Azizi, M. R. Ehsani, M. S. Yarmand and S. H. Razavi. (2008). Effect of microencapsulation and resistant starch on the probiotic survival and sensory properties of synbiotic ice cream. Food Chem 111:50-55

Horaczek, A. and H. Viernstein (2004). Beauveria brongniartii subjected to spray-drying in a composite carrier matrix system. J Microencapsul 21: 317-30

Huys, G., M. Vancanneyt, K. D’Haene, V. Vankerckhoven, H. Goossens and J.Swings (2006). Accuracy of species identity of commercial bacterial cultures intended for probiotic or nutritional use. Res Microbiol 157: 803-810.

Itsaranuwat, P., K. S. H. Al-Haddad and R. K. Robinson (2003). The potential therapeutic benefits of consuming 'health-promoting' fermented dairy products: a brief update. Int J Dairy Technol 56:203-10.

Jay, J. M., M. J. Loessner and D. A. Golden (2005) Modern Food Microbiology, Springer, New York, p.790.

Kailasapathy, K and K. Sultana (2003). Survival of $\beta$-D-galactosidase activity of encapsulated and free Lactobacillus acidophilus and Bifidobacterium lactis in ice-cream. Aust J Dairy Technol 58:223-227

Kailasapathy, K. (2006). Survival of free and encapsulated probiotic bacteria and their effect on the sensory properties of yoghurt. LWT - Food Science and Technology 39:12211227

Kailasapathy, K. and L. Masondole (2005). Survival of free and microencapsulated Lactobacillus acidophilus and Bifidobacterium lactis and their effect on texture of feta cheese. Aust J Dairy Technol 60:252-258 
Kailasapathy, K. and S. Rybka (1997). L. acidophilus and Bifidobacterium spp. their therapeutic potential and survival in yogurt. Aus J Dairy Technol 52:28-35

Kailasapathy, K., I. Harmstorf and M. Phillips (2008). Survival of Lactobacillus acidophilus and Bifidobacterium animalis spp. lactis in stirred fruit yogurts. LWT-Food Sci Technol 41:1317-1322

Karimi, R., A. M. Mortazavian and A. G. Da Cruz (2011). Viability of probiotic microorganisms in cheese during production and storage: a review. Dairy Sci Technol 91:283-308

Kaur, H., H. N. Mishra and P. Umar (2009) Textural properties of mango soy fortified probiotic yogurt: optimisation of inoculum level of yogurt and probiotic culture. Int J Food Sci Technol 44:415-24

Kawasaki, S., T. Mimura, T. Satoh, K. Takeda and Y. Niimura ( 2006). Response of the microaerophilic Bifidobacterium species, B. boum and B. thermophilum, to oxygen. Appl Environ Microbiol 72: 6854-6858

Kedia, G., R. Wang, H. Patel an S. S. Pandiella (2007).Used of mixed cultures for the fermentation of cereal-based substrates with potential probiotic properties. Process Biochem 42:65- 70

Kiliç, G. B., H. Kuleansan, I. Eralp and A.G. Karahan (2009). Manufacture of Turkish Beyaz cheese added with probiotic strains. LWT-Food Sci Technol 42(5):1003-1008

Klingberg, T.D. and B.B. Budde (2006). The survival and persistence in the human gastrointestinal tract of five potential probiotic lactobacilli consumed as freeze dried cultures or as probiotic sausage. Int J Food Microbiol 109: 157-159

Koh. D., Y. Yang, L. Khoo, S. Z. Nyunt, V. Ng and C.L. Goh (2004) Salivary immunoglobulin A and lysozyme in patients with psoriasis. Ann Acad Med Singapore 33:307-310

Korbekandi, H., A. M. Mortazavian and Iravani, S. (2011) Technology and stability of probiotic in fermented milks. In Probiotic and Prebiotic Foods: Technology, Stability and Benefits to the human health, pp. 131-169; Shah, N., A.G. Cruz and J.A.F Faria (Eds.) Nova Science Publishers, New York.

Kourkoutas, Y., L. Bosnea, S. Taboukos, C. Baras, D. Lambrou and M. Kanellaki (2006). Probiotic cheese production using Lactobacillus casei cells immobilized on fruit pieces. J Dairy Sci 89: 1439-1451

Krasaekoopt, W., B. Bhandari and H. C. Deeth (2004). The influence of coating on some properties of alginate beads and survivability of microencapsulated probiotic bacteria. Int Dairy J 14:737-43

Krasaekoopt, W., B. Bhandari and H. C. Deeth (2005). Survival of probiotics encapsulated in chitosan-coated alginate beads in yogurt from UHT- and conventionally treated milk during storage. LWT Food Sci Technol 8:193-195

Krasaekoopt, W., B. Bhandari and H. Deeth (2003). Evaluation of encapsulation techniques of probiotics for yoghurt. Int Dairy J 13:3-13

Lambo, A. M., R. Oste and M. G. E. L. Nyman (2005). Dietary fibre in fermented oat and barley $\beta$-glucan rich concentrates. Food Chem 85:283-93

Lay, C., L. Rigottier-Gois, K. Holmstrøm, M. Rajilic, E. E. Vaughan, W.M. deVos, M. D. Collins, R. Thiel, P. Namsolleck, M. Blaut, and J. Doré (2005). Colonic microbiota signatures across five northern European countries. Appl Environ Microbiol 71: 4153-4155 
Lee, K. Y. and T. R. Heo (2000). Survival of Bifidobacterium longum immobilized in calcium alginate beads in simulated gastric juices and bile salts solution. Appl Environ Microbiol 66:869-73

Lee, Y. K. and S. Salminen (2009). Handbook of probiotics and prebiotics, $2^{\text {nd }}$ ed. John Wiley \& Sons, Inc. Hoboken, New Jersey. Canada. pp 596.

Lucas, A., I. Sodini, C. Monnet, P. Jolivet and G. Corrieu (2004) Probiotic cell counts and acidification in fermented milks supplemented with milk protein hydrolysates. Int Dairy J14, 47-53

Maragkoudakisa, P. A., C. Miarisa, P. Rojeza, N. Manalisb, F. Magkanarib, G. Kalantzopoulosa and E. Tsakalidou (2006). Production of traditional Greek yogurt using Lactobacillus strains with probiotic potential as starter adjuncts. Int Dairy J 16(1):52-60

Martensson, O., R. Oste and O.Holst (2002). The effect of yoghurt culture on the survival of probiotic bacteria in oat-based, non-dairy products. Food Res Int 35:775-84.

Martın-Diana A.B and C. Janer, C. Pel'aez and T. Requena (2003). Development of a fermented goat's milk containing probiotic bacteria. Int Dairy J 13: 827-33

Mattila-Sandholm T., P. Myllärinen, R. Crittenden, G. Morgensen, R. Fondén and R. Saarela (2002) Technological challenges for future probiotic foods. Int Dairy J 173-182

Mättö, J., H. L Alakomi, A. Vaari, I. Virkajärvi and M. Saarela (2006) Influence of processing conditions on Bifidobacterium animalis subsp. lactis functionality with a special focus on acid tolerance and factors affecting it Int Dairy J 16: 1029-1037

McMaste, L. D., S. J. Kokott and V. R. Abratt (2005). Use of traditional African fermented beverages as delivery vehicles for Bifidobacterium lactis DSM 10140. Int J Food Microbiol 102:231-237

Meile, L., W Ludwig, U. Rueger, C. Gut, P. Kaufmann, G. Dasen, S. Wenger, and M Teuber. (1997).Bifidobacterium lactis sp. nov, a moderately oxygen tolerant species isolated from fermented milk. Sys Appl Microbiol 20: 57-64

Mizota. T (1996). Functional and nutritional foods containing bifidogenic factors. Bull Int Dairy Found 313:31-35

Mohammadi R., A. M. Mortazavian, R. Khosrokhavar and A.G. Cruz (2011). Probiotic ice cream: viability of probiotic bacteria and sensory properties. Ann Microbiol 61:411424

Mohammadi, R. and Mortazavian A. M. (2011). Review Article: Technological Aspects of Prebiotics in Probiotic Fermented Milks. Food Rev Int 27:192-212

Mortazavian A. M., S. Ghorbanipour, M. A. Mohammadifar and M. Mohammadi (2011). Biochemical Properties and Viable Probiotic Population of Yogurt at Different Bacterial Inoculation Rates and Incubation Temperatures. PHILIPP AGRIC SCIENTIST, 94 111-116.

Mortazavian AM, Mohammadi R, Cruz AG, Faria JAF (2011) Technology and Stability of Probiotics in Dairy Desserts, In: Shah NP (Ed.) In Probiotic and Prebiotic Foods: Technology, Stability and Benefits to the human health, pp. 233-252; Shah, N., A.G. Cruz and J.A.F Faria (Eds.) Nova Science Publishers, New York.

Mortazavian, A. M. and S. Sohrabvandi (2006). Probiotics and Food Probiotic Products; based on dairy probiotic products. Tehran: Eta Publication 
Mortazavian, A. M., M. R. Ehsani, S. M. Mousavi, S. Sohrabvandi and J. Reinheimer (2007a). Effect of refrigerated storage temperature on the viability of probiotic microorganisms in yoghurt. Int J Dairy Technol 59:123-127.

Mortazavian, A. M., S. H. Razavi, M. R. Ehsani and S. Sohrabvandi (2007b). Pronciples and methods of microencapsulation of probiotic microorganisms. Iran J Biotech 5:1-18

Mortazavian, A.M., R. Khosrokhvar, H. Rastegar and G. R. Mortazaei (2010). Effects of dry matter standardization order on biochemical and microbiological characteristics of freshly made probiotic Doogh (Iranian fermented milk drink). Ital J Food Sci 22: 98102

Mortazavian. A. M., M. R. Ehsani, A. Azizi, S. H. Razavi, S. M. Mousavi, S. Sohrabvandi andJ. A. Reinheimer (2008). Viability of calcium-alginate-microencapsulated probiotic bacteria in Iranian yogurt drink (Doogh) during refrigerated storage and under simulated gastrointestinal conditions. Aust J Dairy Technol 63:24-29

Muianja, C. M. B., J. A Narvhus, J. Treimo and T. Langsrud (2003). Isolation, characterisation and identification of lactic acid bact'eria from bushera: a Ugandan traditional fermented beverage. Int J Food Microbiol 80:201-210

Mustafa, S., A. Shaborin, B. M. Kabeir, A. M. Yazid, M. N. Hakim and A. Khahtanan (2009). Survival of Bifidobacterium pseudocatenulatum G4 during the storage of fermented peanut milk (PM) and skim milk (SM) products. Afr J Food Sci 3:150-155

Nazzaro, F., F. Fratinni, R. Coppola, A. Sada and P. Orlando (2009). Fermentative ability of alginateprebiotic encapsulated Lactobacillus acidophilus and survival under simulated gastrointestinal conditions. J Funct Foods 1:319-23

Nobakhti, A. R., M. R. Ehsani, S. M. Mousavi and A. M. Mortazavian (2009). Influence of lactulose and Hi-maize addition on viability of probiotic microorganisms in freshly made synbiotic fermented milk drink. Milchwissenschaft 64:191-193

Noriega, L., M. Gueimonde, B. Sánchez, A. Margolles and C.G. de los Reyes-Gavilán (2004). Effect of the adaptation of high bile salts concentrations on glycosidic activity, survival at low $\mathrm{pH}$ and cross-resistance to bile in Bifidobacterium. Int J Food Microbiol 94: 79-86

O'Sullivan D.J. (2006). Primary Sources of Probiotic Cultures. In: Goktepe I., V. K Juneja, M. Ahmedna, Probiotics in Food Safety and Human Health. CRC Press,Taylor \& Francis Group, LLC. New York. US. pp 91-109.

Oi, Y. and N. Klitabatake (2003). Chemical composition of an East African traditional beverage, togwa. J Agric Food Chem 51:7024-8

Ong, L. and N. P. Shah (2009). Probiotic Cheddar cheese: influence of ripening temperatures on survival of probiotic microorganisms, cheese composition and organic acid profiles. LWT-Food Sci Technol 42: 1260-1268

Özer, B., H.A. Kirmaci, E. Senel, M. Atamer, and A. Hayaloğlu (2008) Improving the viability of Bifidobacterium bifidum BB-12 and Lactobacillus acidophilus LA-5 in White-brined cheese by microencapsulation. Int Dairy J 19:22-29

Pascual, M., M. Hugas, J. I. Badiola, J. M. Monfort and M. Garriga (1999). Lactobacillus salivarius CTC2197 prevents Salmonella enteritidis colonization in chickens. Appl Environ Microbiol 65: 4981-6

Patrignani, F., P. Burns, D. Serrazanetti, G. Vinderola, J. Reinheimer, R. Lanciotti and M. E. Guerzoni (2009). Suitability of high pressure-homogenized milk for the production 
of probiotic fermented milk containing Lactobacillus paracasei and Lactobacillus acidophilus. J Dairy Res 76:74-82

Perdigon, G., M. Locascio, M. Medici, A. P. D. Holgado and G. Oliver (2003). Interaction of bifidobacteria with the gut and their influence in the immune function. Biocell 27: 1-9

Pico, A. and C. Lacroix (2003). Effect of micronization on viability and thermotolerance of probiotic freeze-dried cultures. Int Dairy J 13:455-462

Possemiers, S., M. Marzorati, W. Verstraete and T. V. de Wiele (2010). Bacteria and chocolate: A successful combination for probiotic delivery Int J Food Microbiol 141: 97-103

Prado, F. C., J. L Parada, J. C. Carvalho, C. R. Soccol (2008). Isolation and characterization of lactic acid bacteria from green coconut microbiota for us in non-dairy probiotic beverage. In: 18 th International Congress of Chemical and Process Engineering. Proceedings: 18th ICCPE. Praga: CHISA 2008. CD. p 1-2

Rada V., Splichal I.., Rockova S., Grmanova M., Vlkova E (2010). Susceptibility of bifidobacteria to lysozyme as a possible selection criterion for probiotic bifidobacterial strains. Biotechnol Lett 32:451-455

Ravula, R. R and N. P. Shah (1998). Effect of acid casein hydrolyzates and cysteine on the viability of yogurt and probiotic bacteria in fermented frozen dairy desserts. Aust J Dairy Technol 53:174-179

Renuka. B., S. G. Kulkarni, P. Vijayanand, S. G. Prapulla (2009). Fructooligosaccharide fortification of selected fruit juice beverages: effect on the quality characteristics. LWT-Food Sci Technol 43:1031-3

Rivera-Espinoza, Y. and Y. Gallardo-Navarro (2010). Non-dairy probiotic products. Food Microbiology 27: 1-11

Roberts, J.S. and D. R. Kidd (2005) Lactic acid fermentation of onions. Food Sci Technol 38:2185-90

Rochet, V., L. Rigottier-Gois, A. Ledaire, C. Andrieux, M. Sutren, S. Rabot, A. Mogenet, J. Bresson, S. Cools, C. Picard, N. Goupil-Feuillerat and J.Doré (2008). Survival of Bifidobacterium animalis DN-173 010 in the faecal microbiota after administration in lyophilised form or in fermented product - a randomised study in healthy adults. J Molecular Microbiol Biotechnol 14:128-136

Ross, R. P., C. Desmond, G. F. Fitzgerald and C. Stanton (2005). Overcoming the technological hurdles in the development of probiotic foods. J Appl Microbiol 98: 1410-1417

Rouhi, M. and A. M. Mortazavian (2010). Probiotic fermented Sausage: Viability of probiotic microorganisms and sensory characteristics. Cri Rev Food Sci Nutr. In press.

Rybka, S and K. Kailasapathy (1997) Effect of freeze drying and storage on the microbiological and physical properties of AB-yoghurt. Milchwissenschaft 52:390394

Rycroft, C. E., M. R. Jones, G. R. Gibson and R. A. Rastall (2001) A comparative in vitro evaluation of the fermentation properties of prebiotic oligosaccharides. J Appl Microbiol 91:878-887

Saarela, M., I .Virkajarvi and H. L. Alakomi (2006). Stability and functionality of freeze-dried probiotic Bifidobacterium cells during storage in juice and milk. Int Dairy J 16: 1477-1482 
Sanders, M and J. Huis in't Veld (1999). Bringing a probiotic-containing functional food to the market: microbiological, product, regulatory and labeling issues. Antonie van Leeuwenhoek 76: 293-315.

Sanders, M. E (2006).Summary of probiotic activities of Bifidobacterium lactis HN019. J Clin Gastroenterol 40: 776-783

Saris, P. E. J., S. Beasley and H. Tourila (2003). Fermented soymilk with a monoculture of Lactococcus lactis. Int J Food Microbiol 81:159-62

Saxelin, B., U. Grenov, R. Svensson, R. Fonden, T. Reniero and T. Mattila-andholm (1999). The technology of probiotics. Trends Food Sci Technol 10:387-392

Saxelin, M., A. Lassig, H. Karjalainen, S. Tynkkynen, A. Surakka, H. Vapaatalo, S. Järvenpää, R. Korpela, M. Mutanen, K. Hatakka (2010). Persistence of probiotic strains in the gastrointestinal tract when administered as capsules, yoghurt, or cheese. Int J Food Microbiol 144: 293-300

Saxelin, M., M. Ahokas and S. Salminen (1993). Dose response on the faecal colonization of Lactobacillus strain GG administered in two different formulations. Microbial Ecology in Health and Disease 6: 119-122

Saxelin, M., R. Korpela and A. Mayra-Makinen (2003). Introduction: classifying functional dairy products. In T. Mattila-Sandholm and M. Saarela, (Eds.) Functional Dairy Products: Vol. 1 (pp. 1-15). Boca Raton, FL: CRC Press,Woodhead Publishing Ltd.

Schmidt, E. J., J. S. Boswell, J. P. Walsh, M. M. Schellenberg, T.W. Winter, C. Li, C.W. Allman and P.V Savage (2001). Activities of cholic acid-derived antimicrobial agents against multidrug-resistant bacteria. J Antimicrob Chemother 47: 671-674

Shah, N. P (2000). Probiotic bacteria: selective enumeration and survival in dairy foods. J Dairy Sci 83: 894-907

Shah, N. P (2001). Functional foods from probiotics and prebiotics. Food Technol 55: 46-53

Shah, N.P. and R. Ravula (2000) Microencapsulation of probiotic bacteria and their survival in frozen fermented dairy desserts. Aust J Dairy Technol 55:139-144

Shah, N.P. and R. Ravula (2004). Selling the cells in desserts. Dairy Indus Int 69:31-32

Sheehan, V.M., P. Ross and G. F. Fitzgerald (2007). Assessing the acid tolerance and the technological robustness of probiotic cultures for fortification in fruit juices. Innovative Food Sci Emerg Technol 8:279-284

Shobharani, P. and R. Agrawal (2009). Supplementation of adjuvants for increasing the nutritive value and cell viability of probiotic fermented milk beverage. Int J Food Sci Nutr 60:70-83

Sousa. R. C. S., R. A. Lira, F. C. Oliveira, D. O. Santos and O. A. P. Sierra (2007). Desenvolvimento e aceitac, , ao sensory de iogurte probi’otico light de banana. In: Proceedings of IX Encontro Regional Sul de Ciencia e Tecnologia de Alimentos. Curitiba, Brazil: Anais do IX ERSCTA. p 549-553

Souza, C. H. B. and S. M. I. Saad (2009). Viability of Lactobacillus acidophilus La-5 added solely or in co-culture with a yogurt starter culture and implications on physicochemical and related properties of Minas fresh cheese during storage. LWT-Food Sci Technol 42:633-640

Steenson, L. R., T. R. Klaenhammer and H. E. Swaisgood (1987). Calcium alginateimmobilized cultures of lactic streptococci are protected from attack by lytic bacteriophage. J Dairy Sci 70:1121-1127 
Sultana, K., G. Godward, N. Reynolds, R. Arumugaswamy, P. Peiris and K. Kailasapathy (2000). Encapsulation of probiotic bacteria with alginate-starch and evaluation of survival in simulated gastrointestinal conditions and in yoghurt. Int J Food Microbiol 62:47-55

Sunohara, H., T. Ohno, N. Shibata and K. Seki (1995). Process for producing capsule and capsule obtained thereby. US Patent 5:478-570

Supavititpatana, P., T. I. Wirjantoro, A. Apichartsrangkoon and P. Raviyan (2008). Addition of gelatin enhanced gelation of corn-milk yogurt. Food Chem 106:211-216

Takahashi. N., J. Z. Xiao, K .Miyaji, and K Iwatsuki (2007). $\mathrm{H}^{+}$-ATPase in the acid tolerance of Bifidobacterium longum. Milchwissenschaft 62:151-153

Talwalkar, A. and K. Kailasapathy (2003). Metabolic and biochemical responses of probiotic bacteria to oxygen. J Dairy Sci 86: 2537-46

Talwalkar, A. I. and K. A. Kailasapathy (2004). The role of oxygen in the viability of probiotic bacteria with reference to L. acidophilus and Bifidobacterium spp. Curr Iss Intest Microbiol 5:1-8

Talwalkar, A., C. W. Miller, K. Kailasapathy and M. H. Nguyen (2004). Effect of packaging materials and dissolved oxygen on the survival of probiotic bacteria in yoghurt. Int J Food Sci Technol 39: 605-11

Tamime, A. Y., M. Saarela, A. K. Sondergaard, V. V. Mistry, and N. P. Shah (2005) Production and maintenance of viability of probiotic microorganisms in dairy products. In: Tamime AY (ed) Probiotic Dairy Products, Blackwell Publishing Ltd, Uk, pp. 39-72

Tannis, A. (2008). Probiotic rescue: how you can use probiotics to fight cholesterol, cancer superbugs, digestive complaints and more, John Wiley \& Sons Canada, Ltd P:269

Thage, B.V., M. L. Broe, M. H. Petersen, M. A. Petersen, M. A. Bennedsen and Y. Ardö (2005). Aroma development in semi-hard reduced-fat cheese inoculated with Lactobacillus paracasei strains with different aminotransferase profiles. Int Dairy J 15:795-805.

Tsen J. H., Y. P. Lin and V.A. King (2004). Fermentation of banana media by using kcarrageenan immobilized Lactobacillus acidophilus. Int J Food Microbiol 91:215-20

Tuorila, H. and A. V Cardello (2002). Consumer responses to an off flavour in juice in the presence of specific health claims. Food Qual Pref 13: 561-569

Ventura M. and G. Perozzi (2011). Introduction to the special issue "Probiotic bacteria and human gut microbiota" Genes Nutr 6:203-204

Ventura, M. and R. Zink (2002) Rapid identification, differentiation, and proposed new taxonomic classification of Bifidobacterium lactis. Appl Environ Microbiol 68: 6429_ 6434

Vinderola, C. G. and J. A. Reinheimer (2003). Lactic acid bacteria: a comparative "in vitro" study of probiotic characteristics and biological barrier resistance. Food Res Int 36: 895-904

Vinderola, C. G., G. A. Costa, S. Regenhardt and J. A. Reinheimer (2002). Influence of compounds associated with fermented dairy products on the growth of lactic acid starter and probiotic bacteria. Int Dairy J 12:579-89.

Vinderola, C. G., W. Prosello, T. D. Ghiberto and J. A. Reinheimer (2000a). Viability of probiotic (Bifidobacterium, Lactobacillus acidophilus and Lactobacillus casei) and non probiotic microflora in Argentinean fresco cheese. J Dairy Sci 83:1905-1911 
Vinderola, C.G., N. Bailo, J. A. Reinheimer (2000b). Survival of probiotic microflora in Argentinian yoghurts during refrigerated storage. Food Res Int 33:97-102

Wang, C., C. C. Ng, W. Tzeng and Y. T. Shyu (2009). Probiotic potential of noni juice fermented with lactic acid bacteria and bifidobacteria. Int J Food Sci Nutr 1:1-9

Wenrong, S. and M.W. Griffiths (2000). Survival of bifidobacteria in yogurt and simulated gastric juice following immobilization in gellan-xanthan beads. Int J Food Microbiol 61:17-26

Yilmaztekin, M., B. H. özer and F. Atasoy (2004). Survival of Lactobacillus acidophilus La-5 and Bifidobacterium bifidum BB-02 in white-brined cheese. Int J Food Sci Nutr 55:5360

Yoon, K. Y., E. E. Woodamns and Y. D. Hang (2004). Probiotication of tomato juice by lactic acid bacteria. J Microbiol 42:315-8

Yoon, K.Y., E.E. Woodamns and Y.D. Hang (2006). Production of probiotic cabbage juice by lactic acid bacteria. Biores Technol 9:1427-30 


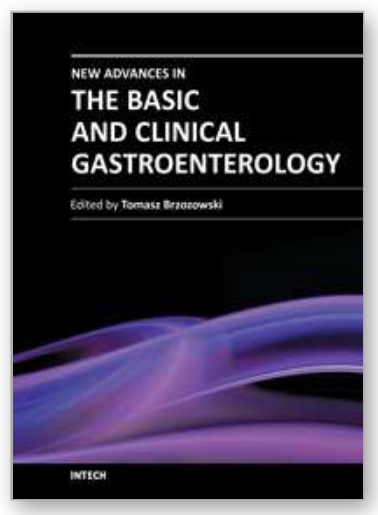

\author{
New Advances in the Basic and Clinical Gastroenterology \\ Edited by Prof. Tomasz Brzozowski
}

ISBN 978-953-51-0521-3

Hard cover, 546 pages

Publisher InTech

Published online 18, April, 2012

Published in print edition April, 2012

The purpose of this book was to present the integrative, basic and clinical approaches based on recent developments in the field of gastroenterology. The most important advances in the pathophysiology and treatment of gastrointestinal disorders are discussed including; gastroesophageal reflux disease (GERD), peptic ulcer disease, irritable bowel disease (IBD), NSAIDs-induced gastroenteropathy and pancreatitis. Special focus was addressed to microbial aspects in the gut including recent achievements in the understanding of function of probiotic bacteria, their interaction with gastrointestinal epithelium and usefulness in the treatment of human disorders. We hope that this book will provide relevant new information useful to clinicians and basic scientists as well as to medical students, all looking for new advancements in the field of gastroenterology.

\title{
How to reference
}

In order to correctly reference this scholarly work, feel free to copy and paste the following:

Amir Mohammad Mortazavian, Reza Mohammadi and Sara Sohrabvandi (2012). Delivery of Probiotic Microorganisms into Gastrointestinal Tract by Food Products, New Advances in the Basic and Clinical Gastroenterology, Prof. Tomasz Brzozowski (Ed.), ISBN: 978-953-51-0521-3, InTech, Available from: http://www.intechopen.com/books/new-advances-in-the-basic-and-clinical-gastroenterology/delivery-ofprobiotic-microorganisms-into-gastrointestinal-tract-by-food-products

\section{INTECH}

open science | open minds

\section{InTech Europe}

University Campus STeP Ri

Slavka Krautzeka 83/A

51000 Rijeka, Croatia

Phone: +385 (51) 770447

Fax: +385 (51) 686166

www.intechopen.com

\section{InTech China}

Unit 405, Office Block, Hotel Equatorial Shanghai

No.65, Yan An Road (West), Shanghai, 200040, China

中国上海市延安西路65号上海国际贵都大饭店办公楼 405 单元

Phone: +86-21-62489820

Fax: $+86-21-62489821$ 
(C) 2012 The Author(s). Licensee IntechOpen. This is an open access article distributed under the terms of the Creative Commons Attribution 3.0 License, which permits unrestricted use, distribution, and reproduction in any medium, provided the original work is properly cited. 